PAWEt DYBAtA ${ }^{1}$

\title{
THE TRANSLATOR IS WRONG!: READERS' ATTITUDES TOWARDS OFFICIAL MANGA TRANSLATIONS BIASED BY FAN-MADE SCANLATIONS
}

\begin{abstract}
The purpose of this paper is to investigate how the knowledge of fan-made translations (scanlations) of Japanese comics (manga) influence the perception of official translations of volumes published in Poland. An analysis is performed on readers' comments regarding the Polish translation of the Dragon Ball Super series and can be seen as a multiple-case study, showing how readers' attitudes can be biased by their knowledge of scanlations (in both English and Polish). Criticism is analyzed using existing translation theories and explained accordingly.
\end{abstract}

Keywords: translation, manga, scanlation, Dragon Ball, fans

\section{INTRODUCTION}

\section{POLISH MANGA MARKET - A SUMMARY}

Japanese comics, commonly known as manga (漫画/まんが/マンガ), are a worldwide phenomenon, also present in Poland. The first manga on the Polish market was published in 1996 by Japonica Polonica Fantastica Publishing House (in the further text abbreviated to J.P.F.). ${ }^{2}$ This ignited

\footnotetext{
${ }^{1} \mathrm{PhD}$; Jagiellonian University in Kraków; ORCID: 0000-0003-2823-7838; pawel.dybala@uj.edu.pl.

${ }^{2}$ See www.jpf.com.pl.
} 
a "manga boom", leading to the current situation in which over 400 mangas are published every year by numerous publishers. ${ }^{3}$

As shown above, it can be stated that manga has become a widely known medium in Poland, one which is commonly available and quite affordable. As most titles popular in Japan are sooner or later published on the Polish market, it is possible to acquire them via official distribution channels. It should also be noted that, to the best of the author's knowledge, most (if not all) manga series currently published in Poland are translated directly from Japanese, by professional and experienced translators with an advanced command of both Japanese and Polish.

\section{FAN-MADE SCANLATIONS}

As stated in section 1.1, in 2020 it is quite possible to acquire in Poland not only all sorts of manga, but also the latest volumes of widely acclaimed series. However, official publications will never be entirely up to date with the Japanese market. In most cases, new chapters of a manga series are first published in magazines (such as Shonen Jump - 少年ジャンプ), often on a weekly basis. The publication of manga series volumes usually takes place at least a few months later, which means that even the latest volumes published in Japan are somewhat delayed when compared with what is available in the magazines.

This leads to a situation in which even if the Polish publication of a series is entirely up to date with Japanese (i.e. new volumes in Poland are published simultaneously with the original ones or shortly after them), the content of these volumes does not cover the latest material published in magazines.

In the Internet era, it is not surprising that much pop culture content can be found online, be it legally or illegally. Although the former is also present on Japanese and global markets in the form of official websites (e.g. Shueisha's [集英社] MANGA Plus), the latter is much more widely represented. The latest chapters of most mangas published in Japan can be easily found on the Internet, in Japanese (so-called "raw scans" or "raws") and in other languages (so-called "scanlations" or "fan translations").

${ }^{3}$ Based on: Rynkowe podsumowanie roku - Mangi w roku 2019. Retrieved December 13, 2020, from https://anime.com.pl/Rynkowe_podsumowanie_roku_-Mangi_w_roku_ 2019, news, read,7027.html. 
Scanlations are usually translated by fans working voluntarily, as a nonprofit activity. Therefore, it is difficult to expect volunteers undertaking such a challenge to be professional translators. Although, as fans, they do possess a vast knowledge of the source material, they may lack the linguistic skills required in order to perform correct translations. This leads to the situation in which scanlations are often up to date with the original Japanese chapters, but lack quality when compared with official publications.

This is even more the case when languages other than English are considered. While English scanlations are usually (albeit not always) translated directly from Japanese, in the case of other languages the route is often more complicated. For instance, most Polish scanlations seem to be translated from English, with only a small amount of cases where translators claim to possess at least some knowledge of Japanese. This leads to another problem: even assuming that the fan translators' linguistic skills and knowledge of English are sufficient to perform such a task, in this case English plays the role of a pivotal language. Thus, it is inevitable that at least some mistakes committed by the Anglophone scanlators will be repeated by those subsequently translating their work into Polish.

To summarize, we are dealing with a situation in which many fans in Poland, desiring to read the latest chapters of their favorite manga series, reach for Polish or English scanlations which are often translated by amateur translators. Thus, it is the fan translation that becomes the first, and often somewhat standard version of these texts, one which with official publications are later compared. This leads to a situation in which all the decisions made by professional translators can be questioned only because they differ from what is known from the scanlations, and thus considered somewhat of a canon.

This, in turn, sometimes results in groups of disappointed fans criticizing official translations. However, it is unsure if, and to what extent, such behaviors influence the sales of the mangas in question, or whether such unsatisfied readers are convinced that professional translators are not necessarily wrong.

\section{OBJECTIVES OF THIS WORK}

The main aims of this paper are: 1) to present the arguments of fans criticizing official translations of manga series published in Poland; 2) to analyze 
the reasons underlying these arguments; and 3) to present the possibilities of convincing readers to give official translations a chance, e.g. by including the fans in the translation process.

Having worked as a manga translator for over sixteen years, the author will use examples from his own work. In this paper, the source material will include examples from Internet discussions concerning the Polish translation of the manga series Dragon Ball Super, focusing on one character's name (Birusu/Beerus/Piwus - see section 4). Although one must concede that, in having been responsible for the translation itself, the author may be perceived as not being entirely objective, it should be stated that the aim of this paper is not to prove that the translator was right. Instead, the focus will be placed on presenting the arguments of readers whose expectations were somewhat biased by fan-made translations. In other words, this work may be seen as a case study, supported with some experience-based remarks.

\section{APPROACHES TO TRANSLATION - COMMUNICATION, EQUIVALENT EFFECT AND "ROOTED TRANSLATIONS"}

Translation is often seen as a sort of intercultural communication. However, it can be also perceived as a form of communication between the sender (author) and receiver (reader), in which the translator plays the role of intermediary between the two. During the process of translation, he or she first takes on the role of the receiver (in reading the original text, analyzing, and trying to understand it), before next becoming the sender (in transmitting the translated content to the readers) (Salmeri, 2016).

What is important in this process is that the translator should take into consideration various factors, including faithfulness - i.e. being faithful both to the sender (by following the author's intentions) and to the receivers (by being aware of their linguistic competences, knowledge, etc.). In other words, the readers expect the translation to be "right", i.e. faithful to the original and, at the same time, capable of being understood. However, as it is shown in section 5 , in some cases these expectations are extended to include such demands as "translate it the way I want" or "I am the customer and you should do everything you can to please me". Some fans even go as far as to state that they are prepared to ignore the author's intentions or the effect the original text has on its readers. 
Such an approach stands in opposition to what Eugene Nida defines as an "equivalent effect" in translation (Nida, 1964). This states that the translated text should trigger possibly the same effects in its readers that the original text did in its own readers. Thus, the argument "this is what the author wanted and what the readers received" should, according to this approach, be sufficient in discussions about the translators' decisions. However, this is not always the case (see section 5).

In one of her works, Ewa Rajewska (2002) proposed the term "rooted translation" - i.e. such a translation that is considered to be somewhat of a "canon" or standard, and one with which other translations are compared. Although this is often the first translation into a particular target language, in the case of manga scanlations in Poland, this approach should also be extended to English translations. In most cases, when a popular manga series is officially published in Poland, it is compared with its rooted translations - i.e. Polish or English scanlations.

\section{SOURCE MATERIAL - DRAGON BALL SUPER}

This paper focuses on the case of Polish readers' reactions to the official translation of the bestselling manga Dragon Ball Super.

Akira Toriyama's (鳥山明) Dragon Ball (ドラゴンボール), published in Japan in 1984-1995, along with its animated adaptation, was a milestone in Japanese pop culture expansion in many countries around the world, including Poland. In 1999, the first episode of anime (アニメ) was shown on the Polish TV cable channel RTL7, sparking a huge boom all over the country. In the same year J.P.F., the first manga publisher in Poland, released the first volume of Dragon Ball manga, which also became a bestseller over the next few years (until 2003, when the last, 42nd volume was published).

In 2015 , twenty years after the last volume, the Japanese publisher Shueisha released the long awaited manga sequel to the series, entitled Dragon Ball Super (ドラゴンボール超) (co-created by the original series' author, Toriyama Akira, and a young mangaka, or manga artist, known as Toyotarou とよたろう). Anime based on this manga premiered later on that year. It is not surprising that in many countries, including Poland, the series was also licensed and published, in response to the many demands of fans. The first Polish volume of Dragon Ball Super was published in 2018. As of December 2020, ten volumes have been released in Poland, and, according 
to the information from the publisher, the series has maintained its position in the top three bestselling mangas. It is also worth mentioning that anime series Dragon Ball Super was broadcast on the Polsat Games channel on Polish cable TV.

It should be noted that many Polish fans had had contact with Dragon Ball Super before its Polish premiere. Soon after the first chapter's release in Japan, numerous fan communities on the Internet started working on scanlations - first in English, then in other languages. The same applies to anime - the latest episodes are immediately translated and published online by fansubbers (fan translators of video content). Therefore, it was possible for Polish fans to read and watch Dragon Ball Super prior to its official release in Poland - also in Polish, as there were at least two scanlation groups that translated the manga and numerous groups that fansubbed the anime (at least one of which claimed to be translating directly from Japanese). However, it seems that most fans preferred English scanlations and fansubs. It should also be noted that, from 2019, the latest manga chapters have been officially published in English on the MANGA Plus online platform run by Shueisha. ${ }^{4}$ Anime, in turn, was available via the Daisuki.net Japanese streaming service, which closed in 2017. Subsequently, anime episodes were available for a short period on the Dragon Ball Super Card Game official website. Currently, they can be watched via the popular streaming service Crunchyroll. ${ }^{5}$

The first forty-two volumes of Dragon Ball were translated into Polish by Rafał Rzepka, a professional and experienced manga translator. However, since he no longer works in this profession, Dragon Ball Super was translated by the author of this paper. In order to remain consistent with Rzepka's version, all his translations (such as proper names) remain unchanged, while new names and terminology are translated according to similar rules, so as to match a given context. Rzepka's translation strategy generally followed the "equivalent effect" rule, assuming that what sounds familiar to a reader of the original version (i.e. in Japanese) should be translated, and what sounds foreign (e.g. in English) should be left unchanged (there were, however, some exceptions to this rule). This rule was also applied in the translation of Dragon Ball Super manga.

\footnotetext{
${ }^{4}$ See https://mangaplus.shueisha.co.jp.

${ }^{5}$ See www.crunchyroll.com.
} 
One of the series' new important characters is a god of destruction named Birusu (ビルス). As this can be associated with the word biiru (ビール), which in Japanese means "beer", it has been translated into English as "Beerus", in both official and fan-made translations of manga and anime. For some readers, it might be rather surprising that such a mighty entity as the universe's god of destruction bears such trivial name - however, it should be noted that contrast like this is somewhat of a trademark of Dragon Ball and its creator, Akira Toriyama. The series protagonist, a very powerful fighter, is called Kakarotto (カカロット), which derives from the word karotto (from the English word "carrot"). His nemesis' name is Furiiza (フリーザ - derived from "freezer"), while one of his friends (and a rival) is called Vegeta (ベジータ - derived from "vegetable").

Taking these into consideration, the name "Birusu" was translated into Polish as "Piwus" (piwo - Polish for "beer") in the official manga translation. However, (probably) all English translations and most other Polish translations (including the Polsat Games anime translation) used the name "Beerus". Only one fansubbers' group decided to translate the name into "Browek" (from browar - a colloquial Polish word for beer).

Therefore, it can be said that in the case of the Polish translation of Dragon Ball Super manga, the "rooted translations" were all the other translations, both into Polish and English, that had been available before the manga itself was officially released - and most of them used the version "Beerus".

\section{ARGUMENTS AGAINST OFFICIAL TRANSLATIONS}

This section presents some examples of discussions that occurred on the Internet after the publication of the first volume of Dragon Ball Super manga in Poland (in 2018). The comments were posted on social media (such as Facebook). They are quoted in Polish (in their unaltered forms - with all the mistakes included and only slight corrections made, such as those due to the lack of fonts displaying Polish diacritic letters) and translated into English. All the comments have been anonymized.

\section{TRANSLATION OF PROPER NOUNS}

One popular stereotype, often referred to in discussions on translations, is that proper nouns should not be translated. This, among others, includes 
the names of characters, artifacts, or places. Many readers seem to share the view that proper nouns are somewhat untouchable and should be left in their original forms. While such a claim had been made in the past by some experts (e.g. Mańczak, 1970), nowadays it is generally agreed that, in some cases, proper nouns can and should be translated.

Here are examples of some comments regarding proper nouns in Dragon Ball Super. All of them were extracted from the official Facebook page of J.P.F. ${ }^{6}$ or discussions on Dragon Ball centered fanpages ${ }^{7}$ or forums, ${ }^{8}$ during discussions on Polish translation that took place in March and April 2018.

Postacie które pojawiły się w anime Dragon Ball Super i które zarazem nie pojawiły się w poprzednich seriach Dragon Balla, mogli już zostawić z oryginalnymi imionami...

(New characters that appeared in the "Dragon Ball Super" anime and were not shown in previous series of "Dragon Ball" could have been left in the original shapes.)

Wygraliście z tym tłumaczeniem... Nikogo by nazwy własne w oryginałach nie bolały.

(Great job, you won... It wouldn't have hurt anyone to leave the original proper nouns in.)

Może jakaś petycja do J.P.F. o nietłumaczenie nazw własnych oraz imion?

(Maybe we should consider a petition to J.P.F. to leave the proper nouns and names alone?)

Dla mnie wszystkie nazwy powinny być oryginalne, włącznie z tytułami. [...] Dlatego o wiele bardziej wolę zagraniczne wydania. [...] przynajmniej nie razi mnie w oczy Piwus.

(To me all the names should be left in the original, including titles. [...] This is why I prefer foreign translations much more. [...] at least names like Piwus don't hurt my eyes.)

Tłumaczenie imion, technik, nazw itp. jest kretyńskie.

(The translation of first names, techniques, and names, etc. is stupid.)

\footnotetext{
${ }^{6}$ See https://www.facebook.com/J.P.Fantastica/.

${ }^{7}$ E.g. https://www.facebook.com/dragonworldpl.

${ }^{8}$ E.g. https://dbnao.net/forum/.
} 
As it can be seen, many comments are quite emotional, which shows the readers' deep engagement in the discussions. In the above-expressed views, fans criticize the decision to translate the name "Birusu" to "Piwus", claiming that it should be left in the "original" form, i.e. "Beerus". This, however, means that one name translation ("Piwus") would have to be replaced by another ("Beerus"), only this time one in English.

Such an approach is a good example of a more common one employed regarding languages and translations, in which foreign words and phrases are preferred over those in one's mother tongue. This is especially present among the fans of Japanese pop culture, which seem to value original names more than translations. However, in this case it seems that the English translation is also preferred over its Polish equivalent.

In this case, the "rooted translation" is not necessarily one particular translation of the original - in fact, it is narrowed down to one version of a name translation ("Beerus").

\section{ALLEGED INCONSISTENCY IN TRANSLATION}

Another argument frequently used in the comments focuses on a perceived lack of consistency in the translation of Dragon Ball Super manga also in comparison with the "old" series. This often concerns proper nouns. Examples are as follows:

Nie mogli już zostawić tego Beerusa? Może Kakarotto też zmienili na Marchewkę.

(Couldn't they have left Beerus unchanged? Did they change Kakarotto to Marchewka [Polish for "carrot"] too?)

Nie toleruję tłumaczenia imion. Nie jestem w stanie tego przetrawić. Nie radziłem sobie z oddziałem Mleckora, Gurtem, Serekiem, Masuo i Kremesem. Piwus jest chyba jeszcze gorszy... Nie wiem czemu nie brną w to dalej i nie tłumaczą Trunksa na „Kąpielówek”. Może brnijmy w to konsekwentnie?

(I can't tolerate the translation of names. I just can't stand it. I didn't like the Mleckor squad members' names either - Gurt, Serek, Masuo and Kremes. Piwus is even worse... Why don't they go further and translate Trunks to "Kąpielówek" [Polish for "swimming trunks"]. Be consistent, right?)

Bo nie nawidzę mang które mają usuwaną swoją oryginalność. Pomyśl np że zbierałbyś Sailor Moon gdzie główną bohaterką jest Królik Tsukino. Bo tak by brzmiało tłumaczenie. Nope for me. Wolę wydanie ze ślicznymi oryginalnymi imionami. 
(Cos I hate it when mangas' originality is removed. Imagine that you buy Sailor Moon where the main protagonist's name is Królik [Polish for "bunny"] Tsukino. Cos that what it would sound like. Nope for me. I prefer those pretty, original names.)

As shown in the examples above, the commenters also referred to translations of other mangas, such Sailor Moon (美少女戦士セーラームーン) by Naoko Takeuchi (武内直子). They also mentioned Mleckor and members of his squad - this refers to the "old" series of Dragon Ball and the socalled Ginyuu Squad (ギ二ュ一特戦隊), whose members' names were also translated to Polish.

Arguments of this type assume that the translator's approach to the translation is inconsistent, which results in a situation in which some names are translated, while other are not. This might theoretically be relevant, as consistent strategies are of great importance in the process of translation; however, in this situation, this is not the case. The authors of these comments seem to be unaware of the strategy mentioned in section 4 (Japanese names are translated, while those which are non-Japanese are left as they are), and thus ironically propose also translating other proper nouns, not only "Birusu".

\section{Humorous Elements that "RUIN the AtMOSPhere"}

Another interesting argument can be seen in the comments such as the one below:

Z tym tłumaczeniem imion przesadzacie, te tłumaczenia stają się coraz bardziej męczące. [...] Czemu Vegeta nie nazywa się u nas Warzywniakiem jakimś? „Walcz ze mną, Marchwiak!” Trochę czasu minęło, parę serii i całkiem sporo sag, Dragon Ball już dawno nie jest tym typem humoru co Dr Slump [...].

(You are going too far with these translations - and I'm getting more and more tired of them. [...] Why isn't "Vegeta" translated to, I don't know, "Warzywniak" [Polish for "vegetable shop"]? And he'd be like, "fight me, Marchwiak!" [from "marchew", Polish for "carrot"]. Come on, a lot of time has passed, as have couple of series and a whole load of sagas, and "Dragon Ball" hasn't shown the kind of humor you see in "Dr Slump" for ages [...].)

$\operatorname{Dr}$ Slump (Dr.スランプ) is another series by Toriyama Akira, although one much lighter and humorous in tone. However, Dragon Ball is also well 
known for its sense of humor and contrasts (see section 4). As this can be seen as the author's trademark, removing the humor from the translation would deprive the readers of a crucial aspect of this manga. It is also worth mentioning that, in an interview published in the first volume of manga, Toriyama stated, that (after two rather serious animated Dragon Ball movies) in Dragon Ball Super he wanted to create something lighter, funnier, and easier to follow (Toriyama, 2015). Thus, erasing the humorous and contrastive elements (such as Birusu/Piwus) would have been against the author's intentions.

\section{Negating the Equivalent EfFect RULE by IgNORING the AUthoR's INTENTIONS}

In the above-mentioned example we could see how the readers can demand that the translator modifies the original text against the author's intentions. Some fans go even further and criticize the creator of their beloved series.

Toriyama to głupek niestety. Fani od zawsze oczekiwali od Dragon Balla agresji, brutalności - niestety zawsze gryzło się to z jego śmieszkowym charakterkiem. To jak wygląda Zetka trzeba zawdzięczać w dużej mierze edytorom pana Toriyamy którzy nie raz odwiedli go od głupich pomysłów, choć ostateczne słowo zawsze będzie należało do niego.

(Sorry, but Toriyama is an idiot. Fans always wanted Dragon Ball to be brutal and aggressive - unfortunately, the author has always been a joker. What Dragon Ball Z looked like is thanks to the editors, who many times have put a stop to Toriyama's stupid ideas. Unfortunately, the last word is always his.)

What is particularly interesting in this comment is that it was posted in reply to the translator's argument that he was trying to be faithful to the author's intentions. Thus, it implies that the translator should go so far as to modify the original in the manner this particular reader prefers, ignoring what the author himself wanted. This is, needless to say, exactly what translators should not do.

Negating the Equivalent Effect Rule by IgNORING THE EFFECT OF THE ORIGINAL TEXT

While some readers criticize the author, other focus on the perception of the receivers of the original text. 
Ja rozumiem twoje rozczarowanie tłumaczeniem imion w DBS, ale nawet jak napiszesz rozprawkę na 100 postów, to nic to nie zmieni. Tom został wydany i tak już zostanie do końca. Też mi się nie podoba tłumaczenie imion i nie przekonuje mnie tłumaczenie, że japoński czytelnik rozumie to tak a nie inaczej.

(I understand that you're disappointed by the translated names in DBS, but even if you write a 100-post-long essay, it won't change a thing. The volume has been published, and the translation will remain the same forever. I don't like the translated names either and I don't buy the explanation that the Japanese reader perceives it this way.)

Jak dla mnie pierwotne zamierzenie jest ważniejsze niż porównanie mnie do japońskiego odbiorcy bo i tak czuję się względem niego pokrzywdzony zmianami, bo Beerus budziło tak jak pierwotnie zamierzano ten niepokój, czego nie budzi Piwus.

(To me the author's primary intention is much more important that the Japanese reader's perception. I am aggrieved by the Polish translation anyway the name Beerus was meant to sound menacing, and Piwus does not.)

In the second comment the reader refers to the "author's primary intention", which is discussed in section 5.8. In both arguments we can see that both the receiver's perception and its equivalence between the original text and the translation is not considered of great importance to some fans.

\section{The Reader as a PAying Customer}

In some cases, readers emphasize that, since they are the customers and are paying for the product, their expectations should be considered of the greatest importance.

Są po prostu ludzie tacy jak ja, co oczekują innego podejścia do tłumaczenia. I irytuje mnie traktowanie takich jak ja podejściem „Ja sprzedaję produkt, wiem lepiej niż wy co powinno się wam podobać, nie tracicie na tym nic, nie macie racji, nie ma was". [...] Widzę to jako oderwanie od rzeczywistości i brak szacunku do mnie jako klienta.

(There are people like me, who expect a different approach to translation. It irritates me when people like me are treated with the attitude "I'm selling you the product and I know better what you like, you don't lose anything, you're not right, you just don't exist". [...] I see that as detachment from reality and a lack of respect for me as a customer.) 
In this case, the reader places the focus on their own expectations, even rights - he or she, as a client, is the one who ought to be pleased by the publisher (and translator), with them agreeing to modification of the original as long as their requirements are satisfied.

Most translators would probably agree that the original can (and sometimes should) be modified - however, the sole motivation of this should not be the desire to satisfy customers.

\section{The Role of Readers' Sentiment AND LACK of TRANSLATOR's ENGAgement}

Another argument that can be seen in discussions about manga translations emphasizes readers' sentiment towards to the series and lack thereof in the case of translators.

Człowieku, czy Ty w ogóle zainteresowałeś się tą mangą?

(Man, are you even interested in this manga?)

Jakbyś zanim się wziął za to tłumaczenie zainteresował bardziej tytułem i szczegółami może pochodzenie tej postaci byś znał.

(If you had been more interested in this comic book before you started translating it, you would know the origins of this character.)

Kiedy od lat jest on [Dragon Ball] w moim top. Na studiach oglądałem anime co pół roku. To daje jakieś dziewięć razy podczas samych studiów. Parodię Abridged widziałem z pięć razy. Do tego masa nieregularnych sesji z tytułem. Nie umniejszaj mojego podejścia do Dragon Balla.

([Dragon Ball] has been at the top of my list for years. During my studies I watched the anime every six months, which makes it about nine times in that period only. The Abridged parody I have seen like five times, plus many irregular sessions with this series. Don't diss my attachment to Dragon Ball.)

Such comments are based on the assumption that for the Polish translator Dragon Ball is nothing more than another assignment, and thus he does not care about the quality of the translation due to their lack of sentiment for it. Setting aside the fact that in this particular case this allegation is not true, we can again see the claim that readers' preferences should be taken into consideration to a greater extent - in this case due to their sentiment for and devotion to Dragon Ball. 


\section{The ROLE OF AUthoR'S PRIMARY INTENTION}

In section 5.5 one of the comments mentioned Toriyama's Akira primary intentions regarding the name "Birusu". This reason occurred also in other posts, such as:

Pierwotne znaczenie imion Beerusa [...] jest znane z wywiadu z panem Yūsuke Watanabe, scenarzystą kinówki „Battle of Gods”. Imię Beerus pierwotnie pochodziło od słowa Virus (w wymowie niemieckiej) [...]. Toriyama potem źle to zrozumiał i myślał, że to od alkoholi, więc dalej tak nazywał resztę bogów zniszczenia i ich aniołów.

(The primary meaning of the name "Beerus" [...] was explained in an interview with Yūsuke Watanabe, the screenwriter of the "Battle of Gods" movie. "Beerus" was supposed to have come from the word "virus" in German pronunciation [...]. Toriyama misunderstood it and thought it comes from alcohol, thus he named other gods of destruction and angels accordingly.)

This comment tackles a very interesting aspect of translation, i.e.: should the creative process be visible in the translated text? Or should we rather focus on the final shape of the original? If we follow the equivalent effect approach, the answer should be the latter - as the misinterpretation of one of the creators cannot be seen in the final text, and thus it is not perceived as part of it by the readers. It should also be taken into consideration that the author (Toriyama) indeed created other characters (gods and angels) bearing names derived from alcoholic drinks in various languages (e.g. Vados ヴァドス - from calvados, Quitela キテラー from tequila, etc.). Therefore, although the misunderstanding mentioned in the comment is said to have actually occurred (as admitted in the interview for Asahi Shinbun 朝日新聞, 2013), it does not need to be taken into consideration in the translation process.

\section{SUMMARY AND POSSIBLE SOLUTIONS}

As shown and discussed in section 5, in many cases readers' comments, although seemingly based on various arguments, actually derive from their knowledge of "rooted translations". This, in turn, causes the shift of focus towards the receivers' expectations and even demands - in some cases accompanied by the belittling of the author's intentions and effects that the 
original text has on its readers. Many commenters also claim that proper nouns (names) should not be translated in general.

To conclude this study, it is worth mentioning that it is in the publisher's (and translator's) best interest to satisfy the readers. That said, the original should not be modified only to achieve this goal. Instead, the focus should be placed rather on convincing the readers that the "official" translation is done by professionals and to their best knowledge and experience. This can be achieved by meetings with the fans, be it online or during conventions, and so on. In some cases explaining the rationale behind particular decisions in translation can also help the readers better understand the original and how it is reflected in the Polish version. This can be done by publishing the translator's notes in Polish-language volumes or during on- and offline discussions. Finally, the fans' vast knowledge of the series can be of great help for the translator - thus, asking some of them to join the translation team as experts can improve the quality of the translation and show the fan community that their voice has been clearly heard by the publisher. In the case of the Polish translation of Dragon Ball Super, such an expert (Adam Gucewicz) has been supporting the translator, starting from the second volume of manga. Moreover, J.P.F. also cooperates with the Facebook fanpage Dragonworld - Swiat Smoczych Kul, ${ }^{9}$ in which it was decided to use the official translations (names, etc.) instead of those preferred by some fans.

The work presented in this paper is a case study, focusing on one manga series and mostly on the translation of one name (Birusu). A more complex study, including other series, should be conducted in order to verify these analyses - as well as, possibly, uncover the relationships between manga genres and the types arguments employed by fans.

\section{BIBLIOGRAPHY}

Asahi Shimbun (2013). Interview with Akira Toriyama (in Japanese). Asahi Shimbun, 30 March (Tokyo).

Mańczak, W. (1970). Onomastyka a strukturalizm. In W. Mańczak, Z zagadnień językoznawstwa ogólnego. (pp. 250-254). Wrocław: Zakład Narodowy im. Ossolińskich.

Nida, E. A. (1964). Toward a Science of Translating. Leiden: E. J. Brill.

${ }^{9}$ See https://www.facebook.com/dragonworldpl. 
Rajewska, E. (2002). „Zakorzenienie” przekładu a polskie tłumaczenia Winnie-the-Pooh Alexandra Alana Milne'a. In P. Fast, K. Żemła (Eds.), Przekład w historii literatury (pp. 59-71). Katowice: Śląsk.

Salmeri, C. (2016). Relacje między oryginałem i przekładem a role uczestników przekładu (na przykładzie angielsko-polskich tłumaczeń). Studia Neofilologiczne. 12, 129-144 (Częstochowa).

Toriyama, A. (2015). Dragon Ball Super, vol. 1. Tōkyō: Shueisha (とよたろう, 鳥山 明: 『ドラゴ ンボール超 1』，集英社，東京，2015). Published in Poland by: Toriyama, A. (2018). Dragon Ball Super, v. 1. Mierzyn: J.P.F.

\section{INTERNET SOURCES}

Anime.com.pl, https://anime.com.pl/Rynkowe_podsumowanie_roku_-Mangi_w_roku_2019, news, read,7027.html. Accessed December 13, 2020.

Crunchyroll, www.crunchyroll.com. Accessed December 13, 2020.

Dragon Ball Nao - forum portalu, https://dbnao.net/forum/. Accessed December 13, 2020.

Dragonworld - Świat Smoczych Kul (Facebook page), https://www.facebook.com/dragon worldpl. Accessed December 13, 2020.

J.P.F., www.jpf.com.pl. Accessed December 13, 2020.

J.P.F. (Facebook page), https://www.facebook.com/J.P.Fantastica/. Accessed December 13, 2020. Manga Plus, https://mangaplus.shueisha.co.jp. Accessed December 13, 2020. 